\title{
The Politics of Professionalization: MPs, Medical Men, and the 1858 Medical Act
}

\author{
M J D ROBERTS*
}

\section{Introduction}

In June and July of 1858 , oppressed by one of the hottest summers on record-a summer which, among other things, required parliamentary staff to hang lime-soaked cloths across the riverside windows of the Houses of Parliament to filter out the stench of a 20 per cent concentration of sewage in the Thames ${ }^{1}$ - the United Kingdom parliament agreed to the passage of a Medical Act. The Act gave statutory recognition for the first time to a distinct occupational category of "legally qualified Medical Practitioner" "entitled according to his Qualification to practise ... in any Part of Her Majesty's Dominions". It also set up a general medical council with powers to monitor standards of professional training, to register qualified practitioners, and to de-register practitioners found guilty of criminal acts or of "infamous conduct in any professional respect". ${ }^{2}$ The Act fell far short of the hopes of some of its medical promoters, especially those who had campaigned for the criminalization of "quackery". Yet it was also the first major bill for medical reform to be passed, after sixteen unsuccessful attempts over the previous eighteen years, and it was in large part for that reason that seasoned campaigners for medical reform such as Thomas Wakley were content to argue that half a loaf was better than none. In similar fashion, more recent historians of the nineteenth-century medical profession have been luke-warm in their evaluation of the Act's significance. They tend to point out all the contextualized ways in which the emergence of a unified profession was destined to happen, with or without legislative encouragement, before grudgingly admitting that, if there is a foundation law of state recognition of the modern British medical profession, then the Act of 1858 is it. ${ }^{3}$ In short, the 1858 Medical Act has

(C) Michael J D Roberts 2009

\footnotetext{
*Associate Professor Michael J D Roberts, Department of Modern History, Macquarie University, North Ryde NSW 2109, Australia; e-mail michael. roberts@mq.edu.au
}

My thanks to the Countess of Wemyss for permission to cite materials in the papers of the Earl of Wemyss, to the Hunterian Librarian of the Royal College of Physicians of London for permission to inspect College records, and to Matt Maley-Bailey for research assistance. This article forms part of a research project supported under the Australian Research Council's Discovery Projects funding scheme.

${ }^{1}$ Dale H Porter, The Thames Embankment, Akron, Ohio, University of Akron Press, 1998, p. 71.
${ }^{2} 21 \& 22$ Vict. c. 90, sections 34, 31, 3, 18, 20, 29 respectively.

${ }^{3}$ Peter Bartrip, Themselves writ large: the British Medical Association 1832-1966, London, BMJ Publishing Group, 1996, pp. 97-8; Penelope J Corfield, Power and the professions in Britain 1700-1850, London, Routledge, 1995, pp. 146-7, 164-5; Irvine Loudon, Medical care and the general practitioner 1750-1850, Oxford, Clarendon Press, 1996, pp. 298-300; Ivan Waddington, The medical profession in the industrial revolution, Dublin, Gill and Macmillan, 1984, p. 96. Cf. Charles Newman, The evolution of medical education in the nineteenth century, London, Oxford University Press, 1957, pp. 192-3. For Wakley on the Act, see Lancet, 14 Aug. 1858, ii: 175 . 


\section{J D Roberts}

generally been presented as a disappointment, both to promoters of medical reform at the time of its passing, and to historians of an emergent British medical profession since.

This article approaches the negotiations surrounding the achievement of state recognition of "medical professionalism" from a different perspective. My aim is to argue for the fruitfulness of an approach to the Act of 1858 which begins from the assumption, not that the Act was "defective", but that what needs investigating and explaining is why it emerged in the shape that it actually took. This approach requires some preliminary clarification of the terms in which the debate was conducted-the rhetoric of "medical reform". It also requires as much attention to be paid to the mental world of the law-makers as to the expressed and implied goals of advocates (and opponents) of medical reform within the emergent medical profession. Finally, it requires an exploration and evaluation of the nature and underpinnings of medical authority in early and mid-Victorian times.

Part of an explanation-a significant part of an explanation for the dismissive historical evaluation of the Act of 1858 it will eventually be seen-lies in the assumptions about the nature of professional authority applied, retrospectively by historians, on the basis of a belief that professionalism denotes a set of ideal characteristics relatively static in meaning over (modern) historical time. As recent historians of science and medicine have reminded us, ${ }^{4}$ this is a recipe for the involuntary importation of teleologyassumption of end intentions-into historical analysis, as indeed frequently happened over the formative generations of the social history of medicine. The first generation, broadly speaking, assumed that professional status relied on the proof of ever-widening advances achieved by specialist division of labour, and identified the recognition of medical professionalism as an aspect of progress towards modern science-based standards of control over human suffering; a second, Foucault-assisted generation, assuming in professional status a mutation of "knowledge" into "power", identified this process of recognition as a technique of "social control" by the self-interested over the manipulable. ${ }^{5}$

In counterpoint to these dominant narratives, there have been, from time to time, those who have recognized that professional authority, however defined, rests on more than professional assertion-that it requires some measure of cultural acceptance as well. ${ }^{6}$ Such acceptance will be evident in historically specific ways, including a society's views on the nature of health and illness, on the nature, purpose and degree of necessity of suffering, and on the plausibility of medical claims to specialist expertise.

\footnotetext{
${ }^{4}$ Ludmilla Jordanova, 'The social construction of medical knowledge', Soc. Hist. Med., 1995, 8 (3): $361-81$, on p. 372 ; and see the extended review of the literature in John C Burnham, How the idea of profession changed the writing of medical history, London, Wellcome Institute for the History of Medicine, 1998, esp. p. 179.

${ }^{5}$ Virginia Berridge, 'Health and medicine', in F M L Thompson (ed.), Cambridge social history of Britain, 1750-1950, vol. 3, Social agencies and institutions, Cambridge University Press, 1990, pp. 171-242, on pp. 171-3; Burnham, op. cit., note 4 above, pp. 114-16, 152-3; Roger Cooter, "Framing" the end of the social history of medicine', in Frank
}

Huisman and John Harley Warner (eds), Locating medical history: the stories and their meanings, Baltimore, MD, and London, Johns Hopkins University Press, 2004, pp. 309-37, on pp. 314-15.

${ }^{6} \mathrm{~S}$ E D Shortt, 'Physicians, science, and status: issues in the professionalization of Anglo-American medicine in the nineteenth century', Med. Hist., 1983, 27: 51-68, on pp. 59-60. For more recent calls for a revisiting of the history of medical professionalization on a "reflexive" basis, see Cooter, op. cit., note 5 above, pp. 326-8; John V Pickstone, 'Medical history as a way of life', Soc. Hist. Med., 2005, 18 (2): 307-23, on p. 321. 


\section{MPs, Medical Men, and the 1858 Medical Act}

The exploration of the Act of 1858 undertaken here attempts to apply these latter insights, aiming to be sensitive to the possibility that in debating, and eventually passing, a distinctive version of medical reform in 1858, MPs were acting to mediate, not just between divergent strands of a still fluidly defined profession, but between professional and lay conceptions of the role of the medical practitioner as well.

\section{Envisioning Reform: Early Victorian Programmes of Professional Advance}

First, then, what did early Victorian campaigners mean when they invoked the slogan, "medical reform"? It will be argued here that they meant one or more of at least four distinguishable programmes of action, each carrying its own cultural baggage. Some of them, along with the assumptions and attitudes attached to them, were mutually reinforcing. Others were mutually antagonistic. Each was developed with a distinctive public audience in mind that had to be persuaded (or at least neutralized) if success were to be gained. And as part of its vision of reform, each had a distinctive perception of the public interest which would be served by implementation of its reform programme. The four visions of reform can be identified in brief as visions of occupational representation, professional status (or "honour"), state service, and market deregulation.

When medical reformers described their task as one of "establishment of the representative principle in governing bodies" (as the British Medical Association founder, Sir Charles Hastings, did in 1858), they did so because it summoned up a familiar and useful set of associational resonances. ${ }^{7}$ What it achieved, in effect, was to link discussion of the distribution of authority within "the medical profession" to debates about citizen entitlement to representation in public life more generally. At its bluntest, it translated to a demand for the "rising" but excluded "majority" of general practitioners in medicine to gain a voice in the corporate decisions of a nationally organized profession of the medically qualified-all those with "property" in their professional skill. This voice, the argument ran, was currently stifled by the monopoly authority of the "medieval", guild-based corporations of the profession, with their increasingly dysfunctional occupational demarcations into physicians, surgeons and apothecaries. ${ }^{8}$ Until these "Gattons" and "Old Sarums" of the medical nation were abolished, as rotten boroughs had been abolished by Schedule A of the Reform Act of 1832, no reliably effective expression of medical authority or purpose could emerge. In practice, it took some time for "disenfranchised" non-metropolitan general practitioners to gain a sense of grievance as intense as articulators of this line of argument suggested was appropriate. However, by 1837 , the Provincial Medical and Surgical Association set up a medical reform committee with representational recognition as part of its brief, and by 1856, when it converted itself into the British Medical Association (BMA), it had become a powerful participant in the debate over medical reform. ${ }^{9}$ Significantly, by then also, it was clear to politicians of both major governing parties that there were, in the words of a

\footnotetext{
${ }^{7}$ Lancet, 22 May 1858, i: 511-13, on p. 511.

${ }^{8}$ For full exposition and evaluation of the argument, see Ian A Burney, 'Medicine in the age of reform', in Arthur Burns and Joanna Innes (eds),
}

Rethinking the age of reform: Britain 1780-1850, Cambridge University Press, 2003, pp. 163-81, on pp. 163-4, 168, 176-81.

${ }^{9}$ Bartrip, op. cit., note 3 above, pp. 71-2, 80, 82 . 


\section{J D Roberts}

Conservative home secretary, "anomalies and absurdities" in an unadjusted system of corporate medical privilege becoming too costly to ignore, both in terms of offending citizens (through religion-filtered professional status conferred by the Oxbridge-linked London Colleges of Physicians and Surgeons) and of inhibiting rational deployment of medical resources in an increasingly mobile age. As the loyal Scot, Lord Elcho, pointed out, it was still, in 1857, a breach of the privileges of the Royal College of Physicians of London, actionable at law, for the celebrated Dr Simpson of Edinburgh to attend on Queen Victoria (unless she was visiting Scotland), even if she asked him to do so. ${ }^{10}$ Naturally enough, there was thought to be a limit to the amount of "democracy" any representative system could safely absorb: John Simon, chief government medical adviser and a key participant in the drafting of the 1858 Act, poured anonymous scorn on the efforts of a previous bill-drafter to have general practitioners nominate and elect their own representatives to a national medical council, imaginatively describing the chaos of contested elections that would ensue and the fanatical policy agendas that would be promoted by "popular" professional politics. ${ }^{11}$ So sponsors of medical reform, both professional and political, were careful to present their plans as "building on existing foundations" (i.e. not abolishing the medical corporations), and distanced themselves from French-style "innovation". Yet, by 1858, it was a commonplace that some representative structure of national medical authority needed to be created.

As the more politically astute had, however, already noted by this stage, the "reform as representation" programme was one with a limited appeal beyond professional circles. Indeed, as the merciless Simon provocatively pointed out, to present "the primary object" of medical reform as if it were no more than the administration of "some property vested jointly in medical corporations and practitioners" was to invite the charge "that professional interests are the only object of medical reform"-a view that "the Legislature will never concede". ${ }^{2}$ To avoid this trap, and to make clear to a wider audience that medical reform was also a necessary step towards service of the public, advocates of representational reform normally invoked a second perspective on medical reform. This situated medical practice in the context of debate about standards of training and practice in "the learned professions" as a whole. The state and the public had an interest in upholding professional privilege, it was argued, because it was a form of privilege earned in exchange for honourable standards of behaviour, i.e. those based on ability to put client welfare before personal advantage in a bargaining situation made inherently unequal by possession of specialist knowledge and skills. ${ }^{13}$ This insight did not necessarily lead in a reformist direction by radical reform standards. At its most culturally conservative the argument might be little more than a declaration of status by ascription-by association with social rank: "He had met one gentleman, the holder

\footnotetext{
${ }^{10}$ Hansard's Parliamentary Debates (hereafter PD) (series 3), vol. 150, cols. 1411-12 (Spencer Walpole, 1858); vol. 135, col. 95 (Lord Palmerston, 1854); vol. 146, col. 724 (Lord Elcho, 1857).

11 'STH', 'Medical legislation', The Times, 22 March 1856, p.10.

${ }^{12}$ Ibid.

${ }^{13} \mathrm{Cf}$. Avner Offer, 'Between the gift and the market: the economy of regard', Econ. Hist. Rev.,
}

1997, 50 (3): 450-76, esp. pp. 450-4, 462-3; Jeffrey Lionel Berlant, Profession and monopoly: a study of medicine in the United States and Great Britain, Berkeley, University of California Press, 1975, pp. 18-25; Eliot Freidson, Professionalism: the third logic, Cambridge, Polity Press, 2001, pp. 198-204, 213-22. 


\section{MPs, Medical Men, and the 1858 Medical Act}

[of a Scots medical degree] who was ignorant of the name of the most commonly known works of Homer", declared one scandalized opponent of medical training uncombined with the preliminary gentlemanly socialization of a degree in classical languages. ${ }^{14}$ More progressively and more commonly, however, the argument could be presented as a need for competitive self-improvement in a self-improving age:

[W] cannot but recognise the principle that all callings are dignified in the scale of modern society exactly in proportion to the mental powers exercised in each, and to the degree of cultivation requisite for entering on the duties... . [I]f the standard of education is lowered, the profession itself must fall in public estimation. ${ }^{15}$

At its most intellectually refined, the status-earning argument might even be blended with the status-preserving argument for presentation as a strand of the socially integrating activity of a Coleridge-inspired "national clerisy" in which the medically qualified stood bonded with clergy and lawyers "as brethren of one household ... bred in one common law of honour". 16

When translated into plans for practical legislative action, this search for peerguaranteed honourable service almost always crystallized into a series of demands for intervention on behalf of the public against the unregulated operation of "market forces" in professional life. Thus it was argued (and widely accepted by non-practitioners) that an unregulated range of training paths into the profession was against the public interest and a threat to standards of professional competence because of the temptation to compete for market share among students of medicine by offering the cheapest, shortest, or least demanding courses of study. ${ }^{17}$ From this flowed an overproduction of practitioners, leading to depression of medical incomes and the further temptation of linking practice, not with the "brains" and "high social position which [belong] to a liberal profession", but with "bottles [and] labels to buy and sell". ${ }^{18}$ The rhetoric of the professional modernization argument, therefore, tended towards (and, before audiences of general practitioners, was as good as guaranteed to achieve) polarization, with providers of medical services divided into qualified practitioners on the one hand and commerce-driven "quacks" on the other. As the uncompromising Thomas Wakley identified the problem in the Lancet:

Quackery, in a thousand shapes ... is the growing vice of modern society, the canker in the bud of our progress ... an age of puffing and falsehood is inaugurated. A short cut has been opened to fortune and to fame.... $[\mathrm{H}]$ omoeopathists, mesmerists, hydropathists, and the like ... are men

\footnotetext{
${ }^{14}$ PD (series 3), vol. 146, col. 745 (Joseph Napier, MP for Dublin University, 1857). For analysis of the cultural background to medical recruitment at midcentury, see M Jeanne Peterson, 'Gentlemen and medical men: the problem of professional recruitment', Bull. Hist. Med., 1984, 58 (4): 457-73.

${ }^{15}$ Lancet, 6 June 1857 , i: 585 . See also $\mathrm{Br}$. med. $J ., 10$ April 1858, i: 294-5.

${ }^{16}$ Joseph Henry Green, Spiritual philosophy, ed. John Simon, 2 vols, London and Cambridge, Macmillan, 1865, vol. 1, p. xix. (Excerpt from lecture given by Green, 1832. Green was to become president of the General Medical Council in 1860.)
}

\footnotetext{
${ }^{17} \mathrm{PD}$ (series 3), vol. 133, col. 117 (Palmerston, 1854); vol. 146, col. 736 (Elcho, 1857); vol. 150, col. 1407 (William Cowper, 1858).

${ }^{18} \mathrm{Br}$. med. J., 8 May 1858 , i: $379-80$, on p. 379 ; $\mathrm{G}$ R Searle, Morality and the market in Victorian Britain, Oxford, Clarendon Press, 1998, pp. 126-7. For "professional overcrowding" before mid-century, see Anne Digby, Making a medical living: doctors and patients in the English market for medicine, 1720-1911, Cambridge University Press, 1994, p. 137.
} 


\section{J D Roberts}

who have sacrificed science and debased morality ... The members of an honourable profession cannot ... hold any terms with them. ${ }^{19}$

As with the case for representation, there were some within (and outside) professional ranks who found this just a little too self-interested to be persuasive in wider public debate. For a start, it seemed to overplay the certainty, and the rate of progress, of medical knowledge at mid-century. ${ }^{20}$ In addition, the elevation of the status of the professionally qualified cut against the public interest not to devalue or to suppress lay participation in domestic self-management unduly. As the radical editor of the Westminster Review (himself on the point of gaining medical qualifications) put it in 1856, medical reformers had become so obsessed with professional qualifications that "they longingly anticipate the time when mothers shall be forbidden to administer castor oil or Godfrey's cordial to their children without [medical] sanction". ${ }^{21}$ None the less, the argument that the public needed a legally enforceable guarantee that medical practitioners could be assumed to have a minimum standard of competence, non-commercially certified, was becoming more plausible to political elites by the mid-1850s.

This predisposition was all the stronger by that point because of the specific experience of governments in tapping medical expertise over the previous generationexperience which had opened up yet a third perspective on medical reform, this time as a way of servicing the policy objectives of the state. These policy objectives defined medical reform and public benefit in yet another set of contexts-that of "public health" or "sanitary science". This public health approach defined the role of medical practice very much in terms of aggregate social outcomes-perhaps not quite Jeremy Bentham's greatest good of the greatest number but certainly something as much communally as professionally defined. And in contrast to the vision of a learned profession serving the expressed needs of self-identifying individual customers in the market place of medical services, public health medicine extended its vision to the need to monitor the whole society, those who could afford to consult the qualified and those who could not.

Two broad developments had stimulated official interest in "public health" as a political issue. The first was the string of contagious disease problems which had, by the 1850 s, resulted from failure of the market to provide public services such as water

\footnotetext{
${ }^{19}$ Lancet, 15 May 1858, i: 483-4, on p. 483. Contemporary observers estimated there were 5,000 to 6,000 offerers of medical services practising on the basis of inadequate or fraudulent qualifications in the mid-1850s, not counting the providers of "traditional remedies": Med. Times Gaz., 30 Oct. 1858, ii: 452; [John Chapman], 'Medical education', Westminster Review, July 1858, 14 (n.s.): 107-62, on p. 107. This figure also did not include pharmacists, whose claims to state recognition had already achieved partial legislative endorsement in the Pharmacy Act of 1852 (15 \& 16 Vict. c. 56) and were protected in the 1858 Act (section 55).
}

\footnotetext{
${ }^{20}$ For an overview, see Roy Porter, The greatest benefit to mankind, London, HarperCollins, 1997, pp. 348-74. For specific mid-century debates, see Logie Barrow, 'Why were most medical heretics at their most confident around the 1840s?: (the other side of mid-Victorian medicine)', in Roger French and Andrew Wear (eds), British medicine in an age of reform, London, Routledge, 1991, pp. 165-85; Alison Winter, Mesmerized: powers of mind in Victorian Britain, University of Chicago Press, 1998, pp. 163-86.

${ }^{21}$ [John Chapman], 'Medical despotism', Westminster Review, April 1856, 9 (n.s.): 530-62, on p. 536.
} 


\section{MPs, Medical Men, and the 1858 Medical Act}

supply and sewage disposal as towns expanded rapidly. The second was the overhaul of government responsibility for enforcing discipline in the labour market-a development which, as implemented under the terms of the Poor Law of 1834, had the paradoxical effect of excluding the "able-bodied poor" from eligibility for support but at the same time of revalidating the claims of the institutionally confined "impotent poor" to a guaranteed minimum level of access to services, including those of a "competent" medical practitioner.

These developments cut two ways. On the one hand, they gave state officials a continuing reason to take an interest in sanitary reform, to think structurally about the purpose of medical expertise and the pattern of its deployment. The certification of a uniform standard of medical competence became a matter of practical political concern because it helped to underpin both social order and labour efficiency. As Thomas Carlyle had already suggested, failed standards of sanitation anywhere in a community had potential effects everywhere. It was on this perception that the surgeon, John Simon, was able to build as he worked his way from successful medical officer of health of the City of London in the 1854 cholera epidemic to increasingly influential adviser at the General Board of Health in 1855, and to the position of medical officer to the Privy Council thereafter. $^{22}$ On the other hand, the chronic underfunding of public health and Poor Law medicine-Poor Law authorities were often tempted to contract out their medical responsibilities to the lowest local bidder ${ }^{23}$-led not only to chronic status-resentment among many general practitioners (thus invigorating grass-roots networks for medical reform) but also to fears among political elites of sponsoring a destabilizing and socially shaming "race to the bottom" in the provision of public medical services. By the mid-1850s the view that government might have a direct responsibility to intervene to guarantee standard minimum levels of protection for consumers, whether voluntary or involuntary, was becoming increasingly familiar to MPs. ${ }^{24}$

Yet even as official circles became convinced of the need to take up medical reform as a responsibility of government, they remained uneasily aware that this would not be an easy decision to propel through public and parliamentary debate onto the statute book because of a fourth perspective on medical reform which refused to accept that "the public interest" could ever be served by such a form of consumer protection. Its proponents promoted "principles of free trade" - an amorphous but widespread set of assumptions about economic and social organization amounting in the post-Corn Law repeal era to something approaching the "cultural default" position for those otherwise uncommitted. ${ }^{25}$ And, unfortunately for other medical reformers, advocates of "medical

\footnotetext{
${ }^{22}$ Royston Lambert, Sir John Simon 1816-1904 and English social administration, London, Macgibbon and Kee, 1963, pp. 230-31. For Carlyle on sanitation, see Past and present [1843], Book III, ch. 2, Book IV, ch. 3. For evaluation of the more complicated realities of mid-Victorian epidemic disease control, see Anne Hardy, The epidemic streets: infectious disease and the rise of preventive medicine, 1856-1900, Oxford, Clarendon Press, 1993, pp. 114-26, 191-203, 290-92.
}

\footnotetext{
${ }^{23}$ Digby, op. cit., note 18 above, pp. 244-7.

${ }^{24}$ PD (series 3), vol. 146, col. 736 (Elcho,1857); vol. 146, col. 752 (Cowper, 1857). See also Wakley's earlier articulations of the same goal cited in Burney, op. cit., note 8 above, pp. 178-9.

${ }^{25}$ See Berlant, op. cit., note 13 above, p. 147, for distinction between market liberalism, libertarianism, laissez faire.
} 


\section{J D Roberts}

free trade" had the capacity to sow doubt in the public mind whichever version was presented. Advocates of reform as a project of representational restructuring found their arguments rejected by populist free traders as mere attempts to modernize monopoly at the expense of English liberties. "This country has already got a State religion and a State education; and it was now about to get State physic", proclaimed radical MP, Tom Duncombe. This was "not what the country required ... The medical reform required was to do away with exclusive privileges of all kinds in the practice of medicine". ${ }^{26}$ Those who proclaimed medical reform as a project of professional modernization based on occupational knowledge and skill faced the flat assertion that it was only by open market competition that either of these credentials could be promoted or reliably ascertained. ${ }^{27}$ And those who claimed that the state had a duty to intervene on behalf of "public health" were warned that efforts to relieve potentially selfmanaging adults of their duty to exercise due care would only lead to future cycles of fecklessness likely to undermine the whole project:

Only by suffering the penalties of employing fools or rogues as their physicians will the people be roused to acquire a knowledge of the simplest elements of physiology and of the laws of health, which would at once enable them to prevent a large amount of disease, and so far to understand what are the essential qualifications of trustworthy professors of the healing art as to be able to select those only who possess them. ${ }^{28}$

None of these arguments was, of itself, insuperable (as the outcome of debate in 1858 was to demonstrate). Yet each muddied the waters, undermined a clear sense of where "the public interest" lay in medical reform, and thus gave an excuse to the uncommitted to put off a decision whenever specific legislative proposals were put forward, only to be contested by some segment of the emergent profession which judged itself disadvantaged. While leading politicians at mid-century acknowledged that "the present condition of the medical profession in this country ... was, in fact, a labyrinth and a chaos", ${ }^{29}$ the issue's notorious intractability made them wary of staking their own reputations on its management.

\section{Enacting Reform: The Debate on the 1858 Medical Act}

The first signs that this situation might possibly change were slow to appear and yet, by 1856 , the preconditions were at last being set in place. As the Palmerston government moved to consolidate its position in the aftermath of the Crimean War, it became important for it to demonstrate its competence in domestic political management. Medical

\footnotetext{
${ }^{26}$ PD (series 3), vol. 146, col. 722 (1857). For the tension between this version of radical reform and the more limited version promoted by Duncombe's companion in radical libertarian causes, Thomas Wakley, see Lancet, 21 Aug. 1858, ii: 205-8, on p. 205; also Burney, op. cit., note 8 above, pp. 178-81; Searle, op. cit., note 18 above, pp. 123-4; Berlant, op. cit., note 13 above, pp. 146-53.
}

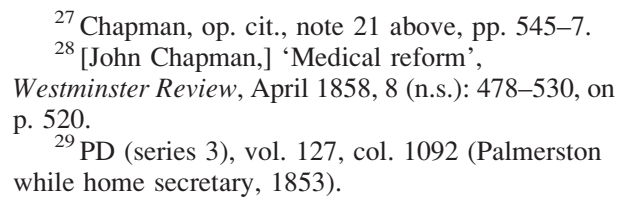




\section{MPs, Medical Men, and the 1858 Medical Act}

reform was one way in which this might be done. After the wartime disasters of "aristocratic mismanagement", government sponsorship of "progressive improvement" in professional training and accreditation formed yet another way to neutralize business-class criticism of inherited privilege, along with a variety of related initiatives in university, civil service, and armed forces reform. ${ }^{30}$

It was in this context that William Cowper, president of the General Board of Health (and Palmerston's stepson), moved to reclaim a government role in medical reform for the first time since the home secretary Sir James Graham had given up in disgust at professional infighting in 1845. Cowper did so by accepting the chair of a Commons select committee appointed in April 1856 to consider the merits of two competing private members' bills. The first, sponsored by T E Headlam, MP for Newcastle, was the bill conceding professional representation to general practitioners, the electoral provisions of which had aroused the scorn of Simon as related above. The second, sponsored by Lord Elcho, was principally concerned to establish a "common portal" of entry to the profession, thus gaining the support of university medical faculties at the expense of alienating the medical corporations. Although the parliamentary session ended before the committee's recommendations could be debated, the fact that the parties had been able to agree on a draft bill ignited the hopes of the general practitioners and the anxiety of the medical corporations in a burst of expectation which, after a further session of government consultation and parliamentary skirmishing, was resolved by Cowper's eventual announcement in December 1857 that he intended to introduce a bill on behalf of the government. ${ }^{31}$ Before he could do so, the Palmerston government fell, to be replaced by a minority Conservative administration, but not before Simon, chief medical officer to the General Board of Health, had completed a draft bill. It was this version of medical reform which Cowper presented to the Commons in March 1858. As might be expected, given the source, the bill was heavily weighted towards a version of medical reform designed to certify the competence of general practitioners. In return for state recognition of the right to practise across "all parts of the United Kingdom", new entrants to the profession would have to "be up to the mark of the science and practice of the day". ${ }^{32}$ In this way, argued Simon in his briefing note to Cowper, the inevitable attack on state protection of registered practitioners against market competition could be neutralized by credible appeal to the public interest. ${ }^{33}$

As was also to be predicted, given the implicit definition of medical reform contained in the bill, the British Medical Association rallied enthusiastically behind Cowper at this point by launching a petitioning campaign. The London corporations, in continuation of

\footnotetext{
${ }^{30} \mathrm{G}$ R Searle, Entrepreneurial politics in midVictorian Britain, Oxford University Press, 1993, pp. 112-25.

${ }^{31}$ For full narrative of events of $1857-8$ from the perspective of the chief medical lobby groups, see Waddington, op. cit., note 3 above, pp. 96-132, supplemented by Bartrip, op. cit., note 3 above, pp. 88-97. For evidence of Cowper's pre-December signals to the medical corporations of his intention to act, see Royal College of Physicians of London (hereafter RCP), Regent's Park, London, MS 2109
}

(Charter and conference committee minute book 1856-62), fols. 14-16, William Cowper to Dr Thomas Mayo PRCP, 17 Sept. 1857 (copy).

${ }^{32}$ William Cowper, The medical practitioners' bill, London, James Ridgway, 1858, p. 4 (an expanded version of Cowper's speech on first reading in the Commons, PD [series 3] vol. 149, cols. 648-51 [1858]).

${ }^{33}$ Special report from the select committee on the Medical Act (1858) amendment (No. 3) bill [Lords], PP 1878-79 (320), XII, p. 305. 


\section{J D Roberts}

insider tactics already launched, sent delegations of their office-holders to lobby incoming Conservative ministers against the bill. University medical faculties, uncertain how best to mobilize their support base, lobbied anxiously among MPs on both sides. Even in the Conservative ministry, however, impatience with medical infighting had begun to have effect and the London corporations found themselves dealing with a home secretary, Spencer Walpole, who had already, on first reading of Cowper's bill in March, declared himself ready to give it conditional support. ${ }^{34}$ All the main players were now fully engaged. Which vision of medical reform was to prevail-or emerge least damaged - in the course of parliamentary debate was now in direct contest. The contest took multiple forms but will be explored here by tracing negotiations centred on three key aspects of debate-the definition of practitioner status, the definition of the training required to obtain that status, and the settlement of the composition of the body set up to preside over practitioner registration, the General Medical Council (GMC).

Who, then, was to be eligible for the status of legally qualified medical practitioners, and with what privileges? Many general practitioners, led by the Lancet, assumed that the answer was self-evident. The point of reform was to drive quacks out of practice, by criminal law penalties if necessary. ${ }^{35}$ The BMA was less strident, demanding penalties only against practitioners claiming to have qualifications they did not possess. As, however, it had adopted a rule (reaffirmed in 1858) that homoeopaths were ineligible for membership of the Association, it too projected a vision of reform intended to separate the orthodox from the unorthodox. ${ }^{36}$ The British Medical Journal's response to the flurry of parliamentary lobbying from "unorthodox" practitioners in defence of their position gave some hint of this: "We scarcely conceived it possible that the Coffinites, homoeopaths, and herbalists, would remain quiet under prospect of a Bill intended to remove them from good and true men; and our anticipations have been correct." 37

As this general practitioner alliance was uneasily aware, however, unorthodox practice had active supporters in parliament (especially in the House of Lords) - and for every supporter they knew of and deplored (Lords Ebury and Elcho, in particular), there were others they failed to detect. These included the 1858 bill's sponsor, Cowper, who took a life-long practical interest in homoeopathy, osteopathy and herbal medicine combined with a settled sense of the limits of practical utility of "orthodox medicine". 38 More unsettling still than the personal eccentricities of outspoken aristocrats was the demonstrable existence of a market to service customer demands for management and

\footnotetext{
${ }^{34}$ PD (series 3) vol. 149, col. 651 (1858). For evidence of Walpole's previous record of interest in medical reform, see PD (series 3), vol. 135, cols. 97-9 (1854).

${ }^{35}$ Lancet, 10 Apr. 1858, i: 368.

${ }^{36} \mathrm{Br}$. med. J., 1 May 1858, i: 351-2; Bartrip, op. cit., note 3 above, pp.75-7.

${ }^{37}$ Br. med. J., 8 May 1858 , i: $373-4$, on p. 373. See Porter, op. cit., note 20 above, pp. 389-96 for explanation of terms.
}

\footnotetext{
${ }^{38}$ For evidence of William Cowper's interest in, and support for "unorthodox medicine", see University of Southampton Library, Broadlands papers, BR43/22/15; also 44/19/7 (obituary pressclipping from Homeopathic World, 1 Nov. 1888). For denunciation of the homoeopathic sympathies of Lords Ebury and Elcho, see Br. med.J., 24 Apr. 1858, i: $337-8$.
} 


\section{MPs, Medical Men, and the 1858 Medical Act}

cure of medical conditions beyond the reach of contemporary medical knowledge to diagnose or treat. This, too, had power to influence MPs. "The great augmentation in the number of people who get cured not according to received rule makes itself felt even in the House of Commons", remarked the disaffected Saturday Review as it put its case for opposing any plan of reform which brought supervision of credential testing under the control of "theologically" driven general practitioners. ${ }^{39}$ For these reasons, while the profession might deplore the unorthodox as market-driven "apostates from true medicine for the sake of pelf", it was never the intention of Cowper's bill to criminalize the supply of services by the unqualified. ${ }^{40}$ The privileges that qualified medical practitioners won by the terms of the bill as introduced (and as enacted) were a monopoly right to have their fees for "medical or surgical advice" recognized as a legally enforceable contractual debt (sections 31-32), and a monopoly on entry to positions in public employment requiring medical qualification (section 36). The price they paid during the debate in both houses was the insertion of clauses specifically prohibiting medical licensing authorities from testing a candidate or removing a practitioner from the register of the qualified "on the Ground of his having adopted any Theory of Medicine or Surgery". ${ }^{41}$ In this way the claims of medical professionalism were blended with the preservation of the individual's liberty/responsibility to remain a free agent in the medical market place.

But what was medical professionalism in the context of the debates of 1858 ? What was to count as professional competence and how would it be guaranteed? The initial formulation of an answer, drafted by Simon in his memorandum of explanation for Cowper, laid heavy emphasis on two matters, the first procedural, the second substantive. In both cases, a "public interest" justification was attached. The procedural guarantee of competence was that institutions providing medical education be persuaded to exercise their examining powers as "a trust for the common good" rather than as a business opportunity in which "income ... increases in proportion as the examination is indulgently marked". The "success" of the London Apothecaries Society and Royal College of Surgeons in attracting candidates to their examinations at the expense of the more highly regarded London University medical school was the basis for this unkind judgement. ${ }^{42}$ The substantive guarantee of competence was the imposition of a "common portal" of entry to professional practice in order to ensure that future entrants to general practice (by far the largest branch of the profession) were trained in both "medicine" and "surgery". To continue the current system in which institutional qualification (outside Scotland) might mean possession of "knowledge of one department of medicine" alone, seemed to Simon "an insecure arrangement for

\footnotetext{
${ }^{39}$ Saturday Review, 10 July 1858, p. 30. Cf. Porter, op. cit., note 20 above, p. 396.

${ }^{40} \mathrm{PD}$ (series 3) vol. 146, col. 750 (1857); vol. 149, col. 648 (1858). Cf. Br. med. J., 24 Apr. 1858, i: 337-8.

${ }^{41} \mathrm{PD}$ (series 3) vol. 151, cols. 999, 2277; Medical Act (1858), sections 23, 28.

${ }^{42}$ PP $1878-79$, XII, pp. 305-6, 309. For a jaundiced but informed review of contemporary
}

levels of practical proficiency required at a range of medical licensing institutions, see Chapman, op. cit., note 19 above, pp. 111-14, 141-52. For a modern review (casting doubt even on 1850s London University medical students), see Thomas Neville Bonner, Becoming a physician: medical education in Britain, France, Germany, and the United States, 1750-1945, Oxford University Press, 1995, pp. 193-5, 215. 


\section{J D Roberts}

the public"-a public which was "but imperfectly informed of these facts or their meaning", 43

It was a powerful and coherent statement but, as presented to the Commons, it did not remain unchallenged. The most intense lobbying against Simon's vision of medical reform was, predictably, that of the medical corporations. This lobbying was directed more at government ministers than at MPs, and its impact on those ministers was successful enough to persuade Cowper that his bill stood no chance in committee unless it incorporated government-drafted amendments. ${ }^{44}$ While later critics, starting with Simon, interpreted these amendments as a triumph of corporate self-interest (which they no doubt were), a study of the reasoning applied in their support by the Conservative ministers most directly engaged in parliamentary management of the matter (Walpole in the Commons and Carnarvon in the Lords) suggests that self-interest was only one of the forces in play. There was a cultural context to Walpole's susceptibility to corporate lobbying. In the first place, Simon's approach to certification of competence seemed too monolithic, too "centralized". It ran the risk of "destroying the benefit now derived from the rivalry" of the twenty-one institutions claiming to give medical training, thus not only interfering with the operation of the free market (assuming it to be capable of self-adjustment over the long term) but also running counter to respect for "English" traditions of incremental reform. ${ }^{45}$ This could be said publicly. More privately, further doubts lurked about Simon's skills-based conception of medical competence. What if seekers after medical assistance were in search of something more than competence? What role might "reciprocity of regard"- a sense of commitment to the patient's needs running beyond the contractual and the scientific-play in the definition of medical practice? Some symbolic reassurance was offered by Simon's inclusion of "infamous conduct" as a ground for removal of practitioners from the medical register but it was not quite enough to remove unease among those who clung to gentlemanly association as a guarantee against patient exploitation. ${ }^{46}$ It was continuing unease of this sort which seems to have prompted the end-of-session diary reflection of Lord Carnarvon on his responsibility as sponsor of the amended bill in the House of Lords-a reflection recording "some doubt as to the ultimate benefits wh[ich] the bill will entail" because of its part in destabilizing the culture of gentlemanly honour fostered by a ranked profession symbolically led by the Royal College of Physicians-a body in which "has hitherto centered [sic] the respectability and the education of the profession". 47

\footnotetext{
${ }^{43}$ PP 1878-79, XII, pp. 306-7.

${ }^{44}$ For bill as amended, see PP 1857-58 (152), III, pp. 477-92. For sample record of lobbying, see RCP, MS 2109 (note 31 above), fols 14-43.

${ }^{45}$ PD vol. 150: 1416 (Walpole); Med. Times Gaz., 22 May 1858, i: 533-4, on p. 534; and see ibid., 24 July 1858 , ii: $90-1$, on p. 90 , for claims of the influence on government of Chapman's "free market" articles cited at notes 21 and 28 above. The conduit appears to have been Lord Stanley: Rosemary

Ashton, 142 Strand: a radical address in Victorian London, London, Chatto \& Windus, 2006, pp. 267-72.
}

\footnotetext{
${ }^{46}$ Medical Act, s. 29; PP 1878-79, XII, p. 309:

"And since the public esteem in which a profession is held must depend on the moral character of its members, not less than on their technical attainments

...". For the actual, highly technical, interpretation of the provision adopted after 1858 , see Russell G Smith, 'The development of ethical guidance for medical practitioners by the General Medical Council', Med. Hist., 1993, 37: 56-67.

${ }^{47}$ British Library (hereafter BL), Carnarvon papers, Add. MSS 60892, fol. 42.
} 


\section{MPs, Medical Men, and the 1858 Medical Act}

In practice, however, the London Colleges did rather well from their lobbying to change Cowper's bill. They failed to substitute themselves as monopoly certifiers of medical competence in place of Simon's new General Medical Council, but they retained the right (subject to Council audit) to set their own examinations. They failed (narrowly) to make registration to practise a form of status recognition based on hierarchical segregation into the pre-existing categories of physician, surgeon and apothecary, but they managed to dismantle Simon's "common portal", thus allowing applicants the choice of registration in either "medicine" or "surgery" (a concession which lasted until 1886). ${ }^{48}$ And, in a symbolic act of defiance against the onset of a market-organized culture, fellows of the Royal College of Physicians preserved their gentlemanly status from the taint of trade by retaining their corporate right to prohibit members from suing in the courts for recovery of debts owed to them for professional advice given (section 31).

A final focus of debate was the question of professional accountability. A key achievement of the bill as enacted was to set up a General Medical Council of the United Kingdom to be responsible for the certification of applicants for registration, and for the preparation of a register of qualified practitioners. The goal itself was relatively uncontroversial. Some executive body was clearly needed for the implementation of any version of medical reform short of a totally deregulated market in medical services. What was controversial was, first, the choice of membership of such a body-the question of representation - and, second, its mechanisms of accountability, the question of who was to guard the guardians.

Simon, as we already know, detested the idea of a Council made up of corporate professional "shareholders", and was also opposed to the idea of profession-wide elections for Council membership. Cowper's bill as originally drafted reflected Simon's attempt to create a Council of nationally representative "trustees" of the public interest without unduly antagonizing the medical corporations. It was to be composed of twenty-three members, nine nominated by the corporations, eight by universities with medical faculties, with six members appointed by the Queen in Privy Council (i.e., by government). As introduced, the bill required the Crown appointees not to be office-bearers in any medical corporation, and it was not mandatory for university appointees to be medically qualified. In the course of debate, the bar on Crown appointments of corporation officebearers was removed but no further amendment was made. The deduction, as was pointed out, was that the GMC might conceivably contain a majority of lay members. ${ }^{49}$ The most curious aspect of the debate about lay representation, however, lay in the fact that the Crown appointees were actually assumed by the medical press (and by a variety of medical reform advocates) to be likely to be laymen. This likelihood both the BMA

\footnotetext{
${ }^{48}$ Full narrative in Waddington, op. cit., note 3 above, pp. 113-23, esp. 121-2; Bartrip, op. cit., note 3 above, pp. 101-2. For the underhand last-minute manoeuvre to retain 'Schedule D' (registration preserving hierarchy of professional status) as an option, and the furious anti-collegial response it evoked, see Carnarvon papers, BL Add. MSS 60850,
}

fols. 52-113. For Cowper's advance warning to the government that this would happen, see fols. 16-17: William Cowper to Lord Carnarvon, 19 July 1858. The matter was finally resolved by the Medical Act Amendment Act, 22 Vict. c. 21, section 3.

${ }^{49}$ Br. med. J., 14 Aug. 1858, ii: 682. 


\section{J D Roberts}

and university representatives actively welcomed, arguing that it would "ensure fair play to the majority of the profession" by "oblig[ing] the medical corporation men on [the Council] to work out the bill in its true spirit". 50

A further glimpse into reformist expectation is given by the post-enactment speculation in the medical press about the likely identity of the president of the new Council. (As finally drafted, section 4 of the Act gave the Council the right to nominate a twenty-fourth member to be its presiding officer.) Two lines of speculation flourished. One body of opinion, recalling the ultimate fate of Edwin Chadwick's General Board of Health, struck down by MPs in 1854 for its lack of accountability to parliament, expected the post would be used to establish a direct line of accountability-and defence opportunity-by being filled by a government minister or at least by an experienced MP. Cowper was the widely acclaimed front runner. Another body of opinion, encouraged by recent Palmerstonian attempts to introduce life peerages as a means of adapting the aristocracy to the needs of a merit-rewarding age, hoped for a sign of acceptance of medical practitioners as men of public honour equal in rank to bishops and law lords. ${ }^{51}$

In the event, none of these speculations proved accurate. The government moved to select Crown appointees entirely from among the medically qualified. They included Sir Charles Hastings, president of the BMA - a partial, though, to many an inadequate, act of conciliation of general practitioners denied "direct representation" by the Act. ${ }^{52}$ The Council, on first meeting, elected the president of the Royal College of Physicians of London, Sir Benjamin Brodie, as its president also; and, despite a "premature" announcement by the Lancet, the government did not make him a peer. ${ }^{53}$ The curiosity of this situation lies in the fact that the medical profession was so willing-or at very least resigned-to leaving resolution of these matters to government ministers and MPs. An occasional outburst of resentment made its way to the surface. "Why is our profession held in so little esteem by the higher classes?" pondered the Medical Times and Gazette in the aftermath of Brodie's non-elevation-this in spite of the fact that "the study of Medicine" required "the highest intelligence" in aiming to pursue "objects ... of the purest and most ennobling character". ${ }^{44}$ But in general, the leaders of all the key medical lobbying groups acquiesced. Their acquiescence alerts us to our final task: the evaluation of the nature of the "authority" of the mid-Victorian medical profession.

\footnotetext{
${ }^{50}$ Ibid.; National Register of Archives (Scotland), Charteris family, Earls of Wemyss and March: letters of the tenth Earl of Wemyss (microfilm) (hereafter Wemyss papers), RH4/40/2, Dr J Y Simpson to Lord Elcho, 21 Aug. 1858. See also the recollection of disappointment of Dr Henry Acland (foundation GMC representative for Oxford) that the government had rejected his strong representations on behalf of lay Crown appointees in 1858: Royal commission to inquire into the Medical Acts, PP 1882 (C.3259-1), XXIX, p. 542 (Q. 42).
}

\footnotetext{
${ }^{51}$ For acclamation of Cowper as an acceptable GMC chairman, see Br. med. J., 16 Oct 1858, ii: 875 . For hopes that any medical professional appointed chairman might be made a peer, see $\mathrm{Med}$. Times Gaz., 13 Nov. 1858, ii: 499-501; 4 Dec. 1858, ii: 576-7. Cf Searle, op. cit., note 30 above, pp. $133,161$.

${ }^{52} \mathrm{Br}$. med. J., 23 Oct. 1858, ii: 888-9; Lancet, 30 Oct. 1858 , ii: $458-60$, on p. 459.

${ }^{53}$ Lancet, 4 Dec. 1858 , ii: 583 ; Br. med. J., 4 Dec. 1858, ii: $1009-10$.

${ }^{54}$ Med. Times Gaz., 14 Dec 1858, ii: 577.
} 


\section{MPs, Medical Men, and the 1858 Medical Act}

\section{Evaluating Reform: Victorian Legislators and Medical Authority}

From one perspective, to some observers, the question of medical authority is a relatively simple one. As one MP summed it up in 1857: "[I]f there were one profession ... concerning which it was almost impossible for non-professional persons to be judges of the manner in which that profession ought to be conducted ... it was this very profession of medicine". 55 And yet authority is a relationship-based attribute: it requires validation by those who submit to it as well as by those who exert it. If all MPs had been as convinced of the self-validating nature of medical authority as their predecessor of 1857 had been, debate in 1858 would have taken a very different path of resolution, or possibly of renewed, professionally generated, stalemate.

In practice, what happened, once the implications of the Act of 1858 had become apparent to those who had lobbied for "medical reform" in the years before, was a continuation of the campaigns whose objectives had not been achieved by reform as enacted. Most eager to explore and, if possible, to extend the limits of reform as enacted were militant general practitioners determined to use the Act to identify and stigmatize quacks: "[T]here is a sort of professional rat hunt, or battue, going on through merry England at this festive time", as Dr Storrar, first GMC representative for London University, explained to Lord Elcho in December of $1858 .^{56}$ When it became apparent that the newly created GMC lacked resources, power, and inclination to take up an active prosecuting role on behalf of the profession, the scene was set for a renewed campaign for direct representation of general practitioners on the GMC itself. This campaign peaked in 1869 with the presentation to ministers and to the GMC of "a memorial in favour of it signed by 9,724 practitioners out of a total of 17,139 on the Medical Directory". 57 Yet again, the differing visions of medical reform cut across each other as the general practitioners' champion, the BMA, attempted to use the mobilization as a bargaining weapon in its efforts to gain the attention of a revived coalition of Simon-led administrative insiders. The BMA's hope was to trade support for Simon's renewed push for mandatory practitioner dual qualification in medicine and surgery in return for greater authority conferred on the GMC to deal with quacks, and for general practitioner representation on the GMC itself. As a result of this tactic and the intraprofessional conflict which it provoked, the officially sponsored bill for dual qualification failed to gain parliamentary support and was withdrawn. ${ }^{58}$

Meanwhile, as the chief disappointed parties of 1858 continued to press their claims, the environment in which medicine was practised continued to mutate. State commitment to the policing of public health and to the provision of medical services to the deserving poor intensified as the implications of standing aloof in a "democratizing" age became less easy to disregard. Medical specialisms and specialist medical 1857).

${ }^{55}$ PD (series 3), vol. 146, col. 716 (John Hatchell,

${ }^{56}$ Wemyss papers, RH4/40/2, Dr John Storrar to Lord Elcho, 29 Dec. 1858. See also Digby, op. cit., note 18 above, p. 28.

\footnotetext{
${ }^{57}$ PP 1882 (C.3259-1), XXIX, p. 532.

${ }^{58}$ Ibid., p. 533; Bartrip, op. cit., note 3 above, p. 100.
} 


\section{J D Roberts}

organizations and publications to support them began to multiply, not least in the field of public health: the Poor Law Medical Officers Association constituted itself a national body in 1868, the Association of Medical Officers of Health-based on Simon's metropolitan initiative of 1856-in 1869..$^{5}$ (The second Reform Act had passed in 1867.) Among private practitioners in general practice in the decades after 1858, the chief challenges to earning a medical living also continued to diversify. By the late 1870 s competition came not only from non-registered practitioners but from an increasing number of "specializing" colleagues within the ranks of the registered profession itself; also from professionally accredited but more openly market-servicing pharmacists, as well as from increasingly well-capitalized advertisers and suppliers of patent medicines. ${ }^{60}$

After a further flurry of Conservative government-assisted investigations of the state of medical training and qualification at the end of the 1870s, legislative resolution was finally achieved under Liberal government sponsorship in the mid-1880s. The Medical Act of 1886 (49 \& 50 Vict. c.48) which embodied the shifted perception of professional medical authority is an instructive document to compare and contrast with the Act of 1858 , as is the record of the parliamentary debate on its passing. As in 1858, its sponsor was able to point to a long pre-history of profession-assisted legislative frustrationtwenty-one or twenty-two bills on the same subject having failed to secure parliamentary support since 1870, according to his calculation. ${ }^{61}$ As in 1858, its sponsor faced the challenge of securing political attention for long enough to achieve an outcome. (The progress of the bill depended on debating time being found at the same time as the debate on Gladstone's first Irish home rule bill.) In contrast to 1858, however, the debate in the Commons was perfunctory, and in the Lords no more than a parochial squabble over allocation of GMC seats within Scotland. In contrast to 1858, the bill as enacted emerged little changed from the intention of its drafters, and lay claims to know better than the profession what medical reform meant were muted. The bill was guided through the Commons by Sir Lyon Playfair, vice-president of the Privy Council and a Liberal MP, but also a qualified scientist much respected by the medical profession as one of their own. ${ }^{62}$

The contents of the bill also conceded much to professional self-regulation. For a start, the bill as enacted-and in the face of Simon's continuing last-ditch opposition to the

\footnotetext{
${ }^{59}$ Jeanne L Brand, Doctors and the state: the British medical profession and government action in public health, 1870-1912, Baltimore MD, Johns Hopkins Press, 1965, pp. 100, 114, note 25; M Jeanne Peterson, The medical profession in mid-Victorian London, Berkeley, University of California Press, 1978, pp. 110-18.

${ }^{60}$ For specialization and its (British) limits in overview during this period, see George Weisz, Divide and conquer: a comparative history of medical specialization, Oxford and New York, Oxford University Press, 2006, pp. 38, 41, 204; Peterson, op. cit., note 59
}

above, pp. 259-72. For general practitioner attempts to insulate their status and income against specialist challenge by consultation fee schedules and referral conventions, see Anne Digby, The evolution of British general practice 1850-1948, Oxford University Press, 1999, pp. 94, 100, 290-91. For pharmacists and patent medicines, see ibid., pp. 227-9.

${ }^{61}$ PD (series 3), vol. 305, col. 236 (Sir Lyon Playfair, 3 May 1886).

${ }^{62}$ Graeme J N Gooday, 'Playfair, Lyon', Oxford Dictionary of National Biography, Oxford University Press, 2004-7, article 22368, vol. 44, pp. 556-60. 


\section{MPs, Medical Men, and the 1858 Medical Act}

idea of the GMC as "the syndicate of some commercial guild of bygone ages" 63 —at last granted general practitioners right of direct representation on the GMC by election of five members (section 7). Simon did at least manage to gain the long-delayed implementation of his goal of a common set of training competences sufficient to guarantee the public that all practitioners registered would have certified proficiency in all "essential branches" of medical practice- "medicine, surgery, and midwifery" (section 2). Yet the Simon-formulated hope that certification would be based on a common curriculum, centrally examined, once again slipped out of GMC reach, with the bill extending the power of the GMC to audit the examinations of medical corporations and university medical faculties without actually displacing them (section 3). ${ }^{64}$ The GMC itself was expanded to include a representative of each medical corporation and each university with a medical faculty in England, Scotland and Ireland, as well as the five elected representatives of the profession and five surviving Crown appointees. In spite of older generation regret that these appointees had always been medical practitioners rather than "statesmen ... persons with great knowledge and experience in the public affairs of the country", and more recent generation willingness to recognize the utility of recruiting the expertise of fellow (but non-medical) professionals to the Council- "men of science" and lawyers each had their supporters-the Crown continued the tradition begun by Spencer Walpole in 1858 that appointees be medical men. ${ }^{65}$ One widely supported goal the profession could not induce the politicians to take up in 1886 was the extension of state regulation over the practice of medicine by "quack" practitioners not claiming to be registered. In this field the market and the right of customers to personal choice continued unrestrained. ${ }^{66}$

Generally, however, the Act of 1886 registered a distinct shift since 1858 in the quality of lay respect for professional authority as defined by the profession itself. How is this to be explained? Three developments are of particular significance. The first concerns institutions and the way in which their evolution encouraged the more self-contained management of intra-professional dispute. The Act of 1858 can hardly be said to have created a united profession but it did give registered practitioners a common status to defend against outsiders. Whereas the generation of practitioners before 1858 had, when provoked, always had the tempting yet tactically dangerous option of appealing to influential lay patrons to redress the balance in disputes with colleagues, this was a less tempting option once the mechanisms for expelling the unqualified or de-registering those guilty of "infamous conduct" were available, however limited the GMC's role in either activity might prove to be. ${ }^{67}$ Even the intra-professional tensions generated by the growth of specialist medical practice in the generation after 1858 were successfully

\footnotetext{
${ }^{63}$ PP 1882, XXIX, p. 509.

${ }^{64}$ For evidence that not all GMC members regretted this situation, see PP 1878-9, XII, p. 31 (Q. 335). See also Newman, op. cit., note 3 above, pp. 236-9; Lambert, op. cit., note 22 above, pp. $580-81$.
}

\footnotetext{
${ }^{65}$ PP 1882, XXIX, pp. 497 (recommendation 22), 542 (Q. 42), 572 (Q. 647).

${ }^{66}$ PD (series 3), vol. 305, col. 247; Digby, op. cit., note 60 above, pp. 33-9.

${ }^{67}$ PP 1878-79, XII, p. 36 (Qs. 240-43, 359, 382-6), and see Smith, op. cit., note 46 above.
} 


\section{J D Roberts}

contained within the profession, thanks no doubt in part to an easing of the problem of "over-supply" of qualified practitioners. ${ }^{68}$

This new-found sense of professional solidarity also owed much to increasing lay respect for what medical practitioners were thought capable of achieving. I stress "thought capable of achieving" because it is now well established that educated public belief in the advance of "scientific knowledge" considerably outran the capacity of medical practitioners to apply such knowledge to clinically reliable effect. ${ }^{69}$ None the less, the perceived success of surgeons in mastering the control of pain by use of anaesthetics in the 1840s was eventually complemented by Lister's introduction of antiseptics in the 1860 s and, while more sober assessors might continue to note that the science of medical practitioners in most areas amounted more to an increased skill in describing and predicting than a skill in curing, there seems little reason to doubt that medical science gained in reputation as a result of its well-publicized successes. ${ }^{70}$ In addition, this consolidation was assisted by the rise of scientific specialization which took place in segregated areas, was reported in language difficult for non-professionals to decode, and addressed specifically to an audience of professional peers-another indication that the profession were becoming able to manage their public reputation more effectively. $^{71}$

Yet scientific reputation and professional solidarity of themselves can hardly give a complete explanation for the evolution of lay trust in professional self-regulation under state sanction. (The year 1886 which produced a profession-friendly Medical Act, also saw the publication of Robert Louis Stevenson's Strange story of Dr Jekyll and $\mathrm{Mr}$ Hyde, a blood-chilling fictional account of "respectable" medical science turned to the service of insatiable "animal" desire for power. It also marked the culmination of a bitter lay revolt against "medical arrogance and cruelty" with the repeal of the Contagious Diseases Acts. ${ }^{72}$ ) A final strand of explanation, as in explanations of 1858, will have to deal with lay perception of medical practice. In 1858, a significant ground of disquiet among MPs and the educated public had been the fear that medical practitioners left to define their professionalism by themselves risked losing that sense of "gentlemanly" responsibility for management of the patient as an individual and instead seeing each case as material for scientific observation and experiment. Two broad trends of the early

\footnotetext{
${ }^{68}$ For British hesitancy to embrace professional specialization, see Christopher Lawrence,

'Incommunicable knowledge: science, technology and the clinical art in Britain 1850-1914', $J$. Contemp. Hist., 1985, 20 (4): 503-20; Weisz, op. cit., note 60 above, pp. 32-43. For generational patterns of professional overcrowding, see Digby, op. cit., note 18 above, pp. 43, 314.

${ }^{69}$ Shortt, op. cit., note 6 above, pp. 58-63;

Lawrence, op. cit., note 68 above.

${ }^{70}$ Digby, op. cit., note 18 above, p. 315 ; and see references cited at note 20 above.

${ }^{71}$ Winter, op. cit., note 20 above, pp. 255, 281; Roger Luckhurst, The invention of telepathy, Oxford
}

University Press, 2002, pp. 12-22; Peterson, op. cit., note 59 above, pp. 281-2.

${ }^{72}$ Martin J Wiener, Reconstructing the criminal: culture, law and policy in England, 1830-1914, Cambridge University Press, 1990, pp. 250-52; Paul McHugh, Prostitution and Victorian social reform, London, Croom Helm, 1980, pp. 248-50; and see Stephanie J Snow, Operations without pain: the practice and science of anaesthesia in Victorian Britain, Basingstoke, Palgrave Macmillan, 2006, for persisting lay distrust of medical use of anaesthetics to the end of the century. 


\section{MPs, Medical Men, and the 1858 Medical Act}

Victorian period had helped to amplify and transmit that sense of unease. From the lay, or patient's perspective, a complex set of cultural interactions, both secular and religious, had begun to transform attitudes to the meaning and management of suffering: in a romantically adjusted age pain became more culturally disturbing, and empathy with the sufferer more culturally admirable. ${ }^{73}$ Yet, from the perspective of general practitioner campaigners for medical reform over the same period, reform more often than not meant asserting one's credentials as a "man of science"-a dedicated observer of the regularities and pathological irregularities of nature - rather than as a comforter with an individual knowledge of the patient. ${ }^{74}$

Once the Act of 1858 was in place, and once the GMC had begun its state-endorsed task of monitoring standards of professional training for accreditation, the potential was in place for an even more aggressively science-based assertion of professional medical competence. Yet what actually happened suggests that the dangers of pursuing such a route towards an exclusively expertise-based definition of medical competence were well recognized by a significant proportion of medical leaders, both within the GMC and among the developers of curricula for medical training. Dr Acland of Oxford, as always a champion of vocation-based approaches to medical training, claimed to have introduced "clinical examinations ... at the bedside of the patient" into the examinable medical curriculum as early as $1859 .{ }^{75}$ Yet he was not alone. By the time of the passing of the Act of 1886, in fact, British medical training had acquired a distinctive reputation abroad-even, indeed especially, in the home of "scientific medical training", Germany-as a training in patient interpretation and management as well as of "scientific knowledge". ${ }^{76}$ In short, it may be argued that the building of educated lay trust in the capacity of medical practitioners to regulate themselves in the generation after 1858 was, at least in part, a consequence of the "rebalancing" of the definition of professional attributes among the leaders of the profession itself.

What this conclusion implies for the history of medicine as a history of professionalization lies, of course, in the eye of the beholder. If we assume that there is an ideal type of professionalism, embodied in independence both from market competition and from lay interference (either state or commercial) in recognition of the efficacy of its specialist expertise, then the Medical Act of 1858 will remain an example of professionalization thwarted and the campaigns fought to "rectify" its imperfections signs of necessary modernization. If, on the other hand, we assume that professional privilege is a negotiated outcome dependent on inherently mutable perceptions of need, efficacy of specialist knowledge, cultural trustworthiness of practitioners, and material return likely to result

\footnotetext{
${ }^{73}$ Among those who came to think so was Spencer Walpole: see his History of England from the conclusion of the Great War in 1815, revised ed., 6 vols, London, Longmans, Green, 1890, vol. 6, pp. 397-8. For shifts in interpretation of the meaning of suffering for the dying and the implications for medical management, see Pat Jalland, Death in the Victorian family, Oxford University Press, 1996, pp. 77-97. For shifts in attitude towards infliction of
}

pain, see, inter alia, Karen Halttunen,

'Humanitarianism and the pornography of pain in Anglo-American culture', Am. Hist. Rev., 1995, 100 (2): $303-34$

${ }^{74}$ Barrow, op. cit., note 20 above, pp. 166-8, 179-81; Winter, op. cit., note 20 above, pp. 158-62.

${ }^{75}$ PP 1878-79, XII, p. 45 (Q. 507).

${ }^{76}$ Bonner, op. cit., note 42 above, 268-76; Lawrence, op. cit., note 68 above, pp. 506-12. 


\section{J D Roberts}

from efforts and resources invested-if we assume all these cultural variables in play, then the Act of 1858 may be evaluated rather differently. Law-makers, it may be deduced, respected medical authority sufficiently to grant medical practitioners national recognition as a profession with state-certified credentials. For reasons of public reassurance, however, MPs also chose a form of privilege-creation heavily weighted in favour of gentlemanly precaution and of customer freedom of choice-an interpretation of "medical reform" which, to some, seemed an anti-climax, even a betrayal, but to others a mere reflection of cultural realities. 